\title{
Life in our hands? Some ethical perspectives on the human genome and human genome diversity projects
}

\author{
Author: \\ Cornelius W. du Toit ${ }^{1}$ \\ Affiliation: \\ ${ }^{1}$ Research Institute for \\ Theology and Religion, \\ University of South Africa, \\ South Africa \\ Correspondence to: \\ Cornelius du Toit \\ Email: \\ dtoitcw@unisa.ac.za \\ Postal address: \\ PO Box 392, University of \\ South Africa 0003 , \\ South Africa \\ Dates: \\ Received: 11 Nov. 2012 \\ Accepted: 28 Oct. 2013 \\ Published: 17 Mar. 2014 \\ How to cite this article: \\ Du Toit, C.W., 2014, 'Life in \\ our hands? Some ethical \\ perspectives on the human \\ genome and human genome \\ diversity projects', Verbum \\ et Ecclesia 35(1), Art. \#812, \\ 10 pages. http://dx.doi. \\ org/10.4102/ve.v35i1.812

\section{Copyright:} \\ (C) 2014. The Authors. \\ Licensee: AOSIS \\ OpenJournals. This work \\ is licensed under the \\ Creative Commons \\ Attribution License.
}

The article dealt with implications of the human genome and the human genome diversity project. It examined some theological implications, such as: humans as the image of God, God as the creator of life, the changed role of miracles and healings in religion, the sacredness of nature, life and the genome. Ethical issues that were addressed include eugenics, germline intervention, determinism and the human genome diversity project. Economic and legal factors that play a role were also discussed. Whilst positive aspects of genome research were considered, a critical stance was adopted towards patenting the human genome and some concluding guidelines were proposed.

\section{Introduction}

\section{Belief in miracles versus science?}

In the February 2001 issue of the scientific journal Nature, the Human Genome Project (HGP) announced that the 'sequencing of human DNA was essentially complete'. ${ }^{1}$ The announcement hails the 21st century as the bio-age. One would expect our world, especially from a human perspective, to be a very different place by the end of the century. It might be a planet on which most of the 5000 or so diseases afflicting humankind are under control, where our predisposition to contract certain diseases has largely been overcome, where genetic technology has 'upgraded' our genetic endowment to 'produce' what amounts to a race of super humans.

It is surely one of the most exciting and creative developments and one with far-reaching consequences for religions. For centuries, sickness and health were the exclusive preserve of religion. Healing was pre-eminently a domain for the performance of miracles. Presently, there is a very real possibility that scientific research over the next few decades may eradicate illnesses that have plagued humankind over the ages. This may ironically be seen as threat to religion and may engender an implicit hostility towards genome research and the promises it holds.

The attention devoted to Jesus' healings exceeds that focused on other experiences. Of the 3779 verses in the four Gospels, 727 relate specifically to the healing of physical and mental illness and resurrection of the dead. Almost a fifth of the synoptic Gospels concerns healings. Some 31 individual healings are recounted and there are at least 20 references to mass healings. ${ }^{2}$

Miracles can be viewed on different levels. The outcome of a difficult problem can be viewed as miraculous or that someone has radically changed his or her way of life. This use of 'miracle' in this context is usually not frowned upon. Our concern here is especially the reference to healing miracles. Many Christian groups, especially those belonging to the Pentecostal tradition, still place a high stake on miracles. But most claims to miracles performed are considered with scepticism by those outside these traditions. Miracles in the religious sphere may still have a symbolic and metaphorical value but few see it as a tangible possibility.

Science, however, promises a viable alternative to miracles. What science has accomplished over the last few decades is no less than a 'miracle'. But not all concur. Many are critical of science in general and specifically of genome research because it further de-mystifies our world. In Christian theology, historical and redaction criticism has already demythologised the Bible; physics and the new cosmology have explained the genesis of the cosmos and now molecular biology has fathomed the mystery of life. Yet theology had made several attempts to account for the New Testament's miraculous healings and Jesus' other miracles in a post-mythology world. They centre on the theology underlying miracles that are to be regarded as symbolic of religion

1.Watson and Crick's brief outline of the double helix structure of DNA was published in Nature on 25 April 1953, less than 60 years ago (Watson 2003:54).

2.We do not imply with this reference that miracles really happened, but want to stress the important role that health has played in religion from the earliest ages. For an updated view on the place of miracles in the New Testament, see John Selby Spong (2007:75-86). Spong rejects unnatural events. Biblical references to such events are '... interpretive narratives far more than they are descriptions of supernatural events' (Spong 2007:81). 
(Jesus), who transforms human wretchedness and suffering; they are signs of a caring God who shares in human suffering and renders it more tolerable. The worldview of 2000 years ago had a different angle on miracles than that of our day. Human experience was full of miracles. We still invoke 'miracles' today, but the context in which they are explained has changed. 'Miraculous arrangement of events' that changed people's circumstances for the better is cited as an instance of God's miraculous intervention in their lives.

But the criticism goes further. Amongst the sayings that are bandied about is that humans are playing God; that we are now able to create our own Frankenstein monsters. ${ }^{3}$ The term 'eugenics' is heard once more: we can breed a race of superhumans, use genetic manipulation to detect disease and nip it in the bud, imprison old age and attain earthly immortality.

Criticism from religious quarters is not new. One need only think of the outcry when steam trains were invented and the dire predictions of the evil it would bring in its wake. But once the new technology is established, the criticism is forgotten and believers lap up the fruits of the new development. Who would say no to the eradication of Down's syndrome, Alzheimer's disease, cystic fibrosis, cancer, AIDS, obesity and illness of whatever kind? Many claim that we have found the elixir of eternal youth; that this marks the beginning of the end of human disease. 'We have discovered the secret of life', Francis Crick cried triumphantly when he and James Watson cracked the code of the DNA structure. What they discovered was indeed the elixir of life. ${ }^{4}$ The process unfolded and still unfolds like a 'whodunit'. One could argue that these developments, far from clearing up the issue of miracles, actually highlight it. The evolution of the genome over millions of years and its outcome that we enjoy today are nothing short of miraculous. Scientific progress, especially in the field of medicine has contributed to a secularised view of healing. Few still expect the impossible to happen but thank God for scientific progress and achievements of modern medicine.

\section{The mystery of life remains intact}

Science, in the modernistic sense of the word, may have contributed to the disenchantment of our world. But this was perhaps inevitable and necessarily part and parcel of emergent insight. Because of science we now know that the development of our cosmos, the nature of life, the working of the human mind and so on is much more fascinating and

3.We refrain from venturing into the cloning debate here. Following lessons learnt from cloning the sheep Dolly, the possibility of cloning humans in future canno be ruled out. 'Right now, we expect efforts to clone human beings to mostly not succeed, and if they did, to result in miscarriages and dead or damaged babies. We also expect that this could easily change as advances in veterinary cloning unveil the answers to the problems with imprinting' (Richards \& Hawley 2005:295).

4.The elixir of life and of immortality (sometimes equated with the philosopher's stone) is a legendary potion or drink that grants the drinker eternal life or eternal youth. Many practitioners of alchemy pursued it. The elixir of life was also said to be able to create life. The philosopher's stone is a legendary alchemical substance said to be capable of turning base metals (e.g. lead) into gold or silver. It was also believed to be an elixir of life, useful for rejuvenation and possibly for achieving immortality. For many centuries it was the most hotly pursued goal of Western alchemy. The For many centuries it was the most hotly pursued goal of Western alchemy. The
philosopher's stone was the cardinal symbol of the mystical terminology of alchemy, philosopher's stone was the cardinal symbol of the mystical terminology
symbolising perfection at its finest, enlightenment and heavenly bliss. complex and miraculous than our forebears could have dreamt. The interconnectedness and interdependence of all life forms, the integrity of our environment and the delicate nature of our atmosphere are now more appreciated than ever before, thanks to science. It would be unbecoming to be hostile to science because it has replaced religion as the main interpreter of creation. Religion has not been usurped by science, although it may now have to change some of its narratives and reinterpret its metaphors.

Although we may have discovered the mystery of life, we still have to learn what life actually is and, more specifically, what if anything makes human life special. ${ }^{5}$ Is life the DNA code or the roughly 30000 genes found in the basis pairs of the chromosome (see Richards \& Hawley 2005:323)? But these are mere building blocks that serve no purpose without the other cell functions. Most of the $98 \%$ so-called junk DNA found in our chromosomes are probably obsolete relics of our evolutionary past, although we may yet discover other operative functions, such as the on-off switch mechanisms that are crucial for cell duplication (Watson 2003:76, 199).

The micro world is no less fascinating than the macro world of the cosmos. Whereas the 9th and 20th centuries were the age of the macro world, the 21st will be the age of molecular biology and medicine.

Conception occurs in a matter of minutes and the zygote takes 9 months to form a foetus ready to start out on life, but the building blocks of the process date back millions of years. Yet amazement may soon yield to reductionism. The moment we are able to explain it the miracle turns into 'nothing but ...'. That goes for our genetic makeup as well. The DNA structure is mind-boggling. The nucleus of every one of our body's 100 trillion cells (not counting blood cells that have no nucleus) have 46 chromosomes (22 pairs comprising one from each parent, and one $\mathrm{XY}$ or $\mathrm{XX}$ pair that determines gender), in which the DNA double helix with its 3 billion base pairs occurs. A mere $2 \%$ of the base pairs comprise some 30000 genes that determine the human blueprint. Yet Homo sapiens' uniqueness is statistically scaled down by the fact that we share most of our genes with other living organisms.

\section{Reductionism?}

If genes are the mystery of life, human uniqueness is scaled down dramatically. Watson (2003:201) cites the following genome statistics: humans have 25000 genes, a mustard plant has 27 000, a fruit fly 14 000, brewer's yeast has 6000 and the intestinal bacterium Escherichia coli has 4000 (bearing in mind that humans have five times more bacteria in their bodies than genes, namely 500 trillion, most of them intestinal). In addition, we share our genes with most other species. Thus we share over $98 \%$ of our genes with chimpanzees and

5.Regis (2008:96-97) maintains that the evolution of life was almost inevitable, given the circumstances on our planet. All that is required for life is a number of proteins that need some amino acid combinations to function. Kauffman (2008:71) writes: 'But we can say at a minimum that it is scientifically plausible that life arose from nonlife, probably here on Earth. It is also plausible that we will succeed in creating nonlife, probably here on Earth. It is also plausible that we will succeed in creating
modestly complex self-reproducing chemical non-equilibrium reaction systems capable of heritable variation.' 
Bonobo monkeys. That does not make $98 \%$ of the human race Bonobo monkeys. People remain unique and differences between individuals are unique, even if they are simply attributable to miniscule genetic variations. The statistics in fact highlight the unity and continuity of human life and nature as a whole.

Some of the genes that we share with others forms of life function better in those species than in humans. Watson (2003:201) mentions that we have 900 genes governing our sense of smell. The encoded proteins are olfactory receptors, each of which recognises a different olfactory molecule or group of molecules. A mouse has approximately the same 900 genes. In humans, some $60 \%$ of these genes have deteriorated in the course of our evolution, probably because of our improved vision. In mice, being nocturnal animals, most of the genes still function.

Reductionism easily turns into relativism. The truism is that all things natural are good. If we are genetically predisposed to a certain behaviour, it must be considered natural and, therefore, good. But in that case, mutations, even unsuccessful ones (aberrations), could be seen as natural and hence as good. Whereas unsuccessful mutations rarely survive in nature, in human culture we care for the handicapped, relieve hunger and combat disease. And it is exactly on this level where human uniqueness comes to the fore. We are part of nature and simultaneously transcend the basic evolutionary-inspired drives for survival. This is the level of human values and the way it translates into ethics. On this level, religious values come into play. Although these values are relative and may change over time important traits remain: to take responsibility for creation, to care for the weak, to have compassion and make sacrifices that go against the constraints of nature red in tooth and claw.

Although we need to recognise this genetic link, it does not reduce human life to lower life forms. Although the human genome can be considered to be the blueprint of life, life is not restricted to its genomic building blocks. Life has always been considered sacred - a God-given miracle we can never emulate. Respect for life is a cornerstone of ethics. Loss of respect for life launches humankind on a hazardous path. Humans are part of nature and are considered sacred by virtue of their mental and spiritual dimensions. But nature in itself is just nature and not sacred. We cannot attribute morality to non-human nature where natural law and evolutionary principles of survival prevail. Sacredness is something we humans attribute to nature. In the course of development since the industrial revolution, the sacredness humans ascribed to nature in bygone times, when nature was unknown, mysterious and threatening, has made way for objectification and exploitation. It is only now that the results of that exploitation are once again looming ominously that there are renewed signs of respect for this earth as our only home. But that does not mean our dominion over nature has ended. It is merely better informed and more sophisticated. Respect for life entails the promotion of life, caring for and preserving life forms, enhancing life, promoting the flourishing of life. Genome research professes to enhance life, eradicate illness and improve quality of life and life expectancy. The question at hand is control and the acceptance of boundaries that may not be crossed (cloning of humans for example).

\section{The question of boundaries in genome research and genetic engineering}

We have indeed opened the Pandora's box of life. But this time, along with the many evils, hope also escaped and remains with us - for instance, hope of overcoming all physical limitations and diseases afflicting humankind through genetic manipulation. What appears to have been left behind in the box is God. To cite another mythological analogy: like Prometheus, we have stolen the fire of the gods. Soon we may have life, health, talents and whatever human attributes we desire at our disposal. But we may burn our fingers in the fire.

One evil that escaped is the possible revival of eugenics. Should a foetus displaying severe genetic abnormalities be aborted? Or once we have discovered how to replace or fix defective genes, could we intervene to upgrade the individual's genetically aberrant DNA to our ideal of what it ought to be? If one of the basic drives behind the evolutionary success story is the survival of the fittest, and we have the ability to 'guarantee' that we will procreate only the fittest specimens of our kind, why not? After all, we would only be applying knowledge already available in nature to improve nature. What may take evolution millennia to achieve we could well accomplish in a decade or two.

In civilised circles eugenics is taboo. By 1941 in the USA, some 60000 people convicted of serious offences or mentally deficient persons had been sterilised. In 1927, a court in Virginia, USA pronounced:

It is better for all the world if, instead of waiting to execute degenerate offspring for crime, or let them starve for their imbecility, society can prevent those who are manifestly unfit from continuing their kind ... Three generations of imbeciles is enough. (Wilson 2003:29)

'Sterilization caught on outside the United States as well - and not only in Nazi Germany. Switzerland and the Scandinavian countries enacted similar legislation' (Watson 2003:29). But sterilisation was still too much trouble and, in 1939, the Nazis started their euthanasia programme. In Watson's (2003:33) words this 'proved a tragedy for humankind'. We now face the possibility of proactively eliminating undesirable elements (disease, character traits) through genetic manipulation. Would that still be natural? The fact is, the whole issue of what is either natural or unnatural has become totally relative.

But it affects not only the physiological and corporeal side of life. Our personal nature is also at stake. Nor do we know 
in how far we are genetically determined. ${ }^{6}$ To what extent do genes account for personality traits, temperament ${ }^{7}$ and aberrant behaviour? In this regard, Watson (2003:166) writes: 'The human genome is the great set of assembly instructions that governs the development of every one of us. Human nature itself is inscribed in that book. ${ }^{8}$ Hence the 'book of life' is an apt metaphor for the genome, for it concerns our understanding of ourselves, our nature and relevance, our link with our forebears and descendants (see Whitt 2009:87).

\section{Early days}

Although enormous progress has been made it is still early days. The 46 chromosomes have been classified according to length. Some 30000 genes occur in these chromosomes, but we are still unsure about their exact function. About 5000 diseases are traceable to genetic defects, but which defect is associated with which gene remains uncertain. Thus the technique of genetic repair is still in its infancy. The enormous amounts being lavished on such research does suggest that it will proceed expeditiously. ${ }^{9}$

A buzzword in the context of genetic manipulation is 'playing God'. Are we not playing God when we tamper with the blueprint of life? In a way, we are playing when we tamper with nature at all. But the theological supposition is that God himself elevated humans to co-creators; human cultural activity is creative activity. The question is, how far should we go and who will set the limits? If we can do something daring, we shall probably do it, especially if it tickles our imagination or our curiosity. The fact is that people will exceed limits wherever they can if it is to their benefit. Is that not a universal law of nature?

Genome research is still in its infancy and already there are taboos: cloning humans, mixing human and animal genes, attempts at breeding a race of superhumans (avoiding all eugenic projects). We are supposed to confine ourselves to replacing mutated genes or repairing malfunctioning ones that can give rise to serious illness. Thus somatic therapy is in order, whereas germline intervention (that tries to alter heredity or produce finer progeny) is frowned upon:

Negatively, germline intervention might help to eliminate deleterious genes that dispose us to disease. Positively, though presently well beyond our technical capacity, such intervention

6.For research conducted on the cellular basis of behaviour, see Kandel (1976) The work focuses on the neurological basis of behaviour and not so much on genetic influences. However, pioneering work on Drosophila has indicated the behavioural genetics and in so doing to shed much additional light on the neural mechanisms of both normal and abnormal behaviour' (Kandel 1976:661).

7.Peters (2003:32) cites a headline from the New York Times of 02 January 1996 'Genetic link found to personality trait: explanation for impulsiveness.'

8. For the question of sexual orientation and genome research see Richards and Hawley (2005:226-235). The possibility of genetically engineering the human race to conform to preconceived ideals may terminate the very essence of life which is its diversity. 'Sexual diversity offers us lessons that can grant us increased understanding of ourselves and our sexuality if we can learn what that sexuality consists of and realize that some of the things we feel are carved in stone are actually variables with real biological underpinnings' (Richards \& Hawley 2005:235).

9.Thus, the 2012 Nobel Prize for medicine or biology was awarded to Sir John Bertrand Gurdon, a British developmental biologist best known for his pioneering research in nuclear transplantation and cloning. He and Shinya Yamanka were awarded the Nobel Prize for the discovery that mature cells can be converted to stem cells. Hence, stem cells need no longer be obtained exclusively from human embryos. should certainly actually enhance human health, intelligence, and strength. (Peters 2003:147)

That would mean that we could intervene even in the embryonic stage to 'upgrade' the genes of the unborn infant in accordance with the parents' notion of their dream child:

Technology simply assists the natural reproductive capabilities of human bodies. Yet the formula contains the latent implication that if persons have the right to obtain children, then they also have the right to obtain desirable children. If a person has the right to use technology to obtain a child that satisfies a subjective parental desire, then using technology to control the qualitative outcome can only serve to intensify that satisfaction. (Waters 2006:39)

So, by and large, therapy is considered a good thing but enhancement is undesirable. That is easily said when we do not know how to do it. If the possibility becomes real, we shall have to confront the issue.

\section{Religious beliefs and the Human Genome Project}

Many religious questions arise as a result of developments in genome research. From the outset the HGP has concerned itself with ethical issues. Firstly, we should note that everything discovered about our genetic building blocks confirms and reinforces the basic evolutionary principles. Nowadays, any religion that wants to remain plausible simply has to accommodate that model. The HGP touches on basic tenets of the Christian faith regarding the role of God as creator and of humans as his creaturely co-creators: God's sacredness and the sacredness of life, the view of nature, humans as the image of $\operatorname{God},{ }^{10}$ our right to decide on sickness, life and death and our right to intervene to prevent diseases and physical defects. This raises new questions about the role of sin and human accountability in light of the fact that our social behaviour is genetically and environmentally determined. Is there a gene responsible for crime and, if there is such a thing as a crime gene ${ }^{11}$ or an alcohol gene (Peters 2003:77-80) or a gene accountable for gender or sexual orientation (Peters 2003:97ff.), what is the role of environmental factors, human freedom and human accountability? Should we put more emphasis on mitigating circumstances if such genetic evidence is available? Will that not reinforce the classical view of predestination? Does it not pose a threat to the church's pastoral ministry (care of the sick) and intercession (gene therapy vs prayer) $?^{12}$ Will it not replace human dependence on God with dependence on science and the financial forces that govern technology?

10.DNA evidence makes it clear, says Spong (2007:237) '... that human life is not just a little lower than the angels as we once taught, but is just a little higher than the apes as we now understand.

11.Peters (2003:70ff.) cites the example of trisomy, men who are born with an XYY instead of an $\mathrm{XY}$ gene on the gender chromosome. Men with an XYY gene were identified amongst serious violent criminals, giving rise to a 'super male' theory to account for male crimes of violence. One male baby in a thousand is born with an $\mathrm{XYY}$ gene and, as Stephen Gould pointed out, most of them live normal lives and
maybe $1 \%$ are in mental-penal institutions (Peters 2003:71).

12.The following quotation puts it in a nutshell: '... either give us patents or we'll give you Alzheimer's! Without patents, all you have left is prayer!' (Peters 2003:127). 
What, if any, are the limits of the permissible use of genetic manipulation in the shaping or modification of agricultural products?

We do not dwell on further implications of the HGP for specific religious doctrines, but content ourselves with the following comments. Religions, and more particularly Christianity, cannot but refrain from taking doctrines based on outdated ideas too literally. Religious notions are always imbedded in the worldview and self-understanding of people in a particular era. Although these may change over time, there are still constants not determined by historical, contingent knowledge that remain pertinent to our selfunderstanding, good interpersonal relations and ways of finding meaning. Amongst these timeless insights are: the role of love and hope, respect for the miracle of life, responsibility for one another and our environment, respect for powers greater than human beings, the place of wisdom that enhances human happiness and good relations, the role of imagination and fantasy in religious experience and many others. Medical advances and the treatment of disease are not tantamount to excising the role of God and transcendence from people's lives. If science, via genetic manipulation or whatever development we can conceive of, can produce 'people' who are no longer dependent on good relations, human attributes such as wonderment, dreams, hopes and yearning, desire, love or whatever other qualities that are subject to religious influence, would they still be human beings? If authentic humanity ceases to exist, so will religion. The notion of a post-human era has been on the agenda for some time now and has to be considered in conjunction with questions that arise from the HGP (Baxi 2007:237; Waters 2006:41-45).

Appleyard (1992:228) claimed that science and our belief in progress have become the religion of our day. The next question is whether the human gene, the blueprint of life, will not usurp God's place as well. Has the dwelling place of the sacred become the domain of the gene? Peters (2003:54) cites three grounds for this idea: 'Three qualities nominate our genome for sacredness: its soul-like quality, its potential for immortality, and its belonging to God's domain.' But the human gene is only one link in a long chain that makes life, particularly meaningful human life, possible. There are innumerable links in the chain of reality that can be isolated as indispensable, but, ultimately, we have to view everything holistically and that is what religion seeks to do.

Whether we like it or not, the fact is that the human genome displays basic religious features. Like the human soul, DNA (according to Peters 2003:54) manifests features of good and evil. DNA raises questions about human freedom and predetermination, both of them major issues in Christian theology, it affects health and illness, a key focus in religion, it concerns eschatology, the doctrine of the end time and the promise of life free from death, pain and tears and it touches on the doctrine that human beings will in fact be given new bodies.
It was clear from the outset that any scientific work on the human genome would have ethical implications. Enormous amounts of money are poured into this research, both by governments and by the private sector. Where money is involved, interests are involved and particular interests are often pursued at the expense of general ones, especially those of parties that are not financially involved. Experience has shown that business ethics are somewhat fuzzy and the deciding factor is often profit. But genome ethics also affects scientists engaging in such research, despite their professed ethical non-involvement or neutrality.

\section{Puppets on a string?}

The ethical issue in the genome debates that captures most attention, apart from eugenics, is probably determinism. If our genes determine us, ethics, human responsibility and freedom are at stake. In his book, Peters (2003) devotes lengthy philosophical and theological discussions to the subject. For lack of space, we cannot dwell on these and so focus on a few comments.

We know that personality and aptitude are genetically codetermined. For example, I may have musical aptitude but unless I develop the talent, I shall probably not become a great musician. Conversely, I may have little or no aptitude but through hard work and commitment I may become a good musician. However, this example cannot simply be generalised. If I am genetically determined to have a particular sexual orientation, no amount of hard work or commitment will change it. If temperament is genetically determined, I would be able to curb socially unacceptable behaviour, but in certain circumstances my temperament may take over. If it ever became possible to 'correct' behaviour genetically, the rich diversity of human nature will go by the board. We are not exclusively determined by our genes at all levels - a belief that Peters $(2003: 52,55)$ calls a gene myth or genetic essentialism.

Determinism is a concept laden with many centuries of philosophical and theological baggage. Often it operates with a generalised concept of linear causality. When we look at the complexity of an organism, let alone the human species, there are so many factors playing a role, by design or by accident, that it is virtually impossible to ascribe a result to a few causal factors (see Neumann Held, Eva \& RehmannSutter 2009:124). This is further complicated by the fact that causal factors may be in constant flux. The same applies to the concept of human freedom that is linked with factors such as desire, volition, intentionality, worldview, values, cultural influence, opportunity, challenges and the like. As these and many other factors contribute to the experience and realisation of freedom to a greater or lesser extent, the concept cannot be pinned down to just some of them. It is the multitude of incalculable factors that characterise the grandeur of the human spirit. 


\section{International guidelines and the problem of patent law Patenting the genome}

Gone are the days when access to knowledge was free. In our information age knowledge costs money. One result is that at tertiary level research is no longer free and spontaneous but depends for funds on large corporations who sponsor research on the basis of profits accruing from the possible research outcomes. The commercialisation of genetic research, especially the matter of patent law in that context, has led to many court cases and a lot of reaction from various interest groups in society:

The commercialization of new genetic technologies, coupled with the trend towards market fundamentalism, clearly redefined the limits of what is considered patentable and what is knowledge in the public domain. (Amani \& Coomby 2007:503)

When Chris Barnard performed the first successful heart transplant on Louis Washkansky in 1967, it did not cross anyone's mind to patent the procedure. Since 2007, some 3500 hearts are transplanted annually, so such a patent could earn a lot of money. Many trail-blazing researchers deserve to be honoured for the discovery of the human genome and most of these pioneers (notably Watson and Crick) did not try to earn money from their work. Watson (2003:67) pays tribute inter alia to Sydney Brenner, a South African who, in 2002, was awarded the Nobel Prize for analysing every amino acid sequence available at the time. In 1961, in collaboration with Crick, he showed that DNA nucleotides are triplet-based (Watson 2003:70).

But the prospect of making a fortune appears to be a major incentive for research. To win the race, J. Craig Venter used the so-called shotgun method to encode, not DNA, but RNA (or mRNA, from which he produced sturdier clones which he called cDNA) (Peters 2003:128; Watson 2003). Venter drew on research to which he had not contributed (Peters 2003:129). Referring to Venter's haste to patent thousands of gene sequences Watson (2003) observes:

In my judgment, the very notion of blindly patenting sequences without knowledge what they are was outrageous: what precisely was one protecting? This conduct could only be seen as a preemptive financial claim on a truly meaningful discovery someone else might yet make. (p. 181)

Many of the pioneers who laid the foundation for knowledge of the functioning and eventual manipulation of genomes made no spectacular profit from their work. Nowadays, that knowledge is used to anticipate future developments that may have financial advantages and researchers apply for patents, however precarious the basis for the claim. Some large companies appoint scientists who identify on which chromosome a gene is located, try to determine what that gene does and what diseases it causes, anticipate genetic engineering and patent the right to perform it on that gene, so that they have a claim to all future profits accruing from manipulation of that gene and treatment of the concomitant illness.
Some of the main ethical problems associated with the HGP boil down to human greed. Patent law is a matter of greed and profits. Interventions by governments and the private sector are all to do with profit. There was a time when health was not for sale. You had to live carefully and look after your health. If it becomes possible to buy health, people will be prepared to pay for it, implying that I can live irresponsibly because whatever damages I incur can be repaired. Incalculable sums will be paid to companies, governments and countries which hold the patents to treat serious diseases or genetic defects. Consider the money the USA has earned from the development of personal computers. In many countries, the right to health and access to health services are considered a human right, but in many others it remains an ideal because it is too expensive. So will access to health and victory over serious diseases caused by genetic defects be reserved for the rich?

There is also the right to privacy. Can insurance companies who gain information on your genetic blueprint refuse to insure you and can employers refuse to employ you on the basis of such information?

Amani and Coomby (2007) cite a decision by the Canadian Council of Churches:

The race to patent genes is at fever pitch. Some think of it as a kind of $21^{\text {st }}$ century gold rush ... What is now being privatized is not common land, but bits of the internal structure of life itself ... the number of patents on human genetic material may already be as high as four million ... Whole movements are afoot to protect 'the genetic commons' but so far those movements are dwarfed by the army of interests championing the new array of intellectual property rights. (pp. 498-499)

Peters (2003:118) refers to a press statement issued on 18 May 1995 by 180 religious leaders, representing 80 different religions and denominations (Buddhist, Hindu, Islamic, Judaic, Christian, etc.), in which they demand a prohibition of patenting the human genome and genetically engineered animals. Peters' (2003:118) response is that these religious leaders are confusing a gene myth with proper science. Probably it is not as simple as that. Peters himself earned good money as an ethicist appointed to provide guidelines for human genome research. He focuses exclusively on the 'playing God' objections of some religious leaders, but never mentions the economic implications or the cause of the poor.

To whom does my genetic code belong? I received it for free. We all receive life for free, which is why we cannot put a price on human life. The American Patent and Trademark Office has laid down that there can be no patent on natural phenomena such as humans, animals or bodily parts. Patents are awarded to new, useful inventions, not to obvious things (Peters 2003:119):

You can't patent something that belongs to everyone. It's like trying to patent the stars ... By patenting something without knowing the use of it, you inhibit industry. This could be catastrophic. (Peters 2003:133) 
If a gene that is considered responsible for a given illness is patented, only scientists employed by the company holding that patent will research it and it may take years to produce meaningful results, if it ever happens at all.

In June 2013, the US Supreme Court ruling on Myriad Genetics' patent rights for BRCA 1 and BRCA 2 held that genes are products of nature and as such not patentable. The mere fact of isolating a gene does not make it eligible for patenting. This judgement enables wider genetic testing and whole genome sequencing and can be regarded as a compromise between the biotechnology industry, public health and scientific research. Whilst genes as products of nature are not patentable, synthetically created DNA is, as are methods and applications. This judgement will inevitably influence legal stances towards genome patenting in the rest of the world.

\section{Genome ethics?}

What is the basis of genome ethics - the Bible, scientific findings, human rights, or the legal sciences? As it is an international project affecting humankind as a whole, the ethics of different religions can hardly be a common denominator. The only basis for such a common denominator would be an international charter of human rights, but even then there would be deficiencies. Without sound knowledge of what genome research is about, ethical guidelines can hardly be justified. Besides, scientists claim to be ethically neutral. Legal ethics could be helpful but is influenced by the context in which its pronouncements are made. In any case, there will be countries that prohibit practices that are allowed in others (human cloning being an example). The problem with formulating an ethics is that its focus is on just one part of a problem, so it loses sight of the whole. The problem is reduced to some viewpoint, enabling us to lay down guidelines and apply them to a reality that far exceeds the particular part. Peters (2003) observes that:

a cell line with a known DNA sequence is not a living being. Even ... DNA ... in itself is not life. Nor is it a human being. Nor is it a person. Therefore, the debate over patenting DNA sequences - regardless of which side one takes - is not a debate over patenting life. (p. 137)

That DNA is not life makes the patenting dispute less fierce and emotional. But without DNA and many other building blocks that have been identified no life is possible and DNA is particularly relevant because it accounts for so many things.

At present, we probably need to consider a combination of the aforementioned influences on the basis of internationally accepted human rights, notably a balance between individual and group rights and the rights to freedom of religion, speech and association. Yet, we know from experience that fine sounding human rights and the ideals that prompt them are usually disregarded when money is at stake. The genome project is unlikely to be an exception.

\section{The Human Genome Diversity Project}

The Human Genome Diversity Project (HGDP) aims to map different population groups. The project arose once the human genome had been mapped. It has fascinating possibilities, like an unexcavated field rich in archaeological information at the genome level. Although the human genome is unique and identifiable, individual genomes differ greatly. So do the genomes of different population groups and the disparities can be used to research archaeological data on migration patterns, incidence of diseases and other environmental factors that influenced the history of particular populations. (For a comparison of individual DNA with that of a particular population group and of other populations, necessary in determining forensic DNA, see M'charek 2005:27-29.) The more isolated a population is, the more valuable the available genome data. "They are deemed the "treasure keepers" of original information, which, in the course of history, had gradually been obscured in other large groups because of migration and admixture' (M'charek 2005:2). Whitt mentions that in an article in the 1991 issue of the journal Genomics, ${ }^{13}$ the HGDP was announced as follows:

The Human Genome Project can now grasp a vanishing opportunity to preserve the record of our genetic heritage ... The genetic diversity of people now living harbors the clues to the evolution of our species, but the gate to preserve these clues is rapidly closing. (Whitt 2009:81)

The value of the project is that it can teach us more about our evolutionary past, that earlier forms of the human genome could hold important keys to diseases afflicting both humankind generally and indigenous groups and that we may gain insight into the earliest migration patterns of Homo sapiens:

The idea is that human genetic makeup is indicative of historical events and vice versa: that the contingency of human history is reflected in the DNA. By tracing similarities and differences in the DNA fragments of various populations, geneticists hoped to provide another [a better?] account of human history. Culture and nature are thus married-up in the Diversity Project. (Whitt 2009:81)

Thus human genealogy can be mapped, maybe as far back as the first identifiable common or 'second' Adam. Isolated populations' genes are preserved and are more homogeneous than those of groups with genetically complex loadings caused by horizontal (intra-group) and vertical (inter-group) mixing.

The most acceptable theory is that the earliest forebears of Homo sapiens migrated northwards from Africa (the Out-ofAfrica theory). The so-called multiple-origin theory, namely that humans originated in various places and parts of the world at roughly the same time and settled there has little support (M'charek 2005:17-18, n. 31). In this regard, southern 13. See Genomics 11, 1991:490 
Africa is very much in the limelight, because there is growing evidence that this is the cradle of human history. ${ }^{14}$ Thus the descendants of the Khoi-San can probably provide invaluable information on the early evolution of the human genome. It is crucial that this should be done before urbanisation erases certain unique genome attributes. What are the rights of these communities in this respect?

\section{Ethical objections}

Originally, a list of 722 population groups was compiled whose genome warranted mapping (Whitt 2009:82). As may be expected from a project involving a lot of money and benefits, politics enters into it. So there was an immediate outcry about the exploitation of ethnically isolated minorities whose genome was to be mapped for the benefit of the wealthy few. The controversy has to be dealt with; it is just as understandable as the patenting controversy in the USA when genome mapping first started. Initially, the possibility of financial benefits from the HGDP was denied, maintaining that, whilst the chances of developing commercially lucrative products are 'very remote ... our current planning anticipates that this unlikely event is not impossible' (Whitt 2009:89). But the basic argument is very clear: the prospect of benefitting financially from the HGDP is by no means certain, but if the project is not undertaken valuable information will be lost forever. The human genome in itself tells us nothing. It calls for hard work, ingenuity and the development of complex technologies to decipher the information.

There is also a human element. We donate blood and donate organs without recompense. If a third party were to cash in on this and the recipient has to pay, it is a very different scenario. If the patenting debacle had not happened in the course of the genome project and the private sector had not proceeded to invest billions in it, the HGDP would probably have been less controversial. This raises the question of whether the battleground should not be shifted to a different forum: the multi-billion dollar scene of multinational medical corporate industries. Should health services not be de-privatised totally and form part of every country's national health policy? (We know that President Obama faces fierce opposition in this regard and that the feasibility of South African schemes on these lines is viewed pessimistically.)

The HGDP has been labelled and widely discredited. One hears about bio-piracy (Whitt 2009:125), bio-colonialism and the vampire project (Whitt 2009:112). M'charek (2005:2) raises the objection that indigenous groups from whom genetic

14.A case in point is the Blombos Cave in the southern Cape where excavations started in 1991. The cave has yielded evidence of our forebears that is far olde than that of the European Cro-Magnon (c. 35000 years ago). Blombos artefacts date back to the Middle and Late Stone Age. Three phases have been identified when the cave was inhabited (there were phases in between when it was uninhabited): the first was about $140000 \mathrm{BCE}$, the second between 140000 and $100000 \mathrm{BCE}$ and the third about $71000 \mathrm{BCE}$. The evidence indicates periods of relatively brief occupation separated by long periods of non-occupation including relatively brief occupation separated by long periods of non-occupation, including a separation between occupation during the Late Stone Age and the Middle Stone Age. Considerable quantities of ochre and associated ochre working tools in the first phase, bone tools in the upper second phase and bone tools, marine shell beads, and engraved ochre were found in the third phase. The Stone Age in southern Africa is divided into the Early Stone Age, or Palaeolithic Period (about $2500000-150000$ years ago), the Middle Stone Age, or Mesolithic Period (about 150 000-30 000 years ago), and the Late Stone Age, or Neolithic Period (about $30000-2000$ years ago) samples are taken are ignorant and are often misled by those who obtain the samples:

We're taking from them their DNA, which we now consider like gold. It's even worse than standard colonialism and exploitation, because we are taking the one thing we value, and after we take that, we have no real interest in whether they live or die. (M'charek 2005:2-3)

Whitt (2009:100, n. 80) mentions dozens of indigenous groups (mainly from North and South America - South Africa is not included) who have protested against the project. United Nations Educational, Scientific and Cultural Organization's (UNESCO's) ethics committee has refused to sign the HGDP (Whitt 2009:114).

Yet, proponents of the HGDP really want to include minority population groups. They find it embarrassing:

... that most human genome research concentrates only on persons from the major ethnic groups in the industrialized countries. Indigenous groups are not being served - and this deliberately ignores their importance as members of the human species. (Whitt 2009:115)

It may sound very noble, but underlying it is the reality that the genome of fairly isolated groups (like the South African San) represents a unique gene pool that may disappear as urbanisation proceeds. Before that happens the gene has to be mapped for the sake of its possible future value.

But if indigenous groups were to refuse to have their genome mapped, would they have any claim to future benefits of genome research based on mapping of other (Western) populations? What about racial prejudice that will inevitably stem from the identification of genome differences based on ethnic diversity? Genome ethics has a political and ethnic aspect as well. Patricia King (in Peters 2003) puts it thus:

The danger to racial and ethnic minorities and the poor from current gene mapping efforts is obvious: the danger is that greater attention will be paid to genetic explanations than to more complex explanations for differences to the detriment of vulnerable and disadvantaged groups. (p. 72)

An important development in the HGP is the International Haplotype Map, or HapMap. Blood samples collected from around the globe will be used to characterise individual genetic differences, using the database sequence as a key for the comparison. The goal is to determine genetic contributions to disease precisely and even tailor drugs to the patient's unique genetic makeup (see Amani \& Coomby 2007:507). HapMap can also be used to highlight slight differences amongst various groups of the human population. If human nature is viewed simply as the sum of the base pairs, then such differences can be used to justify a variety of ill conceived agendas (Hewlett 2004:188). The 'ill conceived agendas' no doubt refers to racial prejudice arising from the findings. There have been various responses to the possibility. Whitt (2009:115) cites a geneticist who said: 'We're not trying to exploit people; we're trying to include them. It's racist to avoid the totality of humans.' Another response was: 
'I know that a race gene does not exist. And that's what the project will show.' Another conciliatory comment reads:

We can acknowledge the diversity of our species only by studying the diversity, not by pretending that an American genome is 'the' human genome ... studying the diversity should help us see better how closely related all humanity is - that we are, in literal fact, an extended family. (Whitt 2009:115)

But ultimately that romanticised 'extended family' will pay for the knowledge. In that respect Amani and Coomby (2007) issue a caveat:

The HapMap Project, by diversifying the targeted populations, should serve as a warning that the relevance of the politics of patents with respect to human genetic research extend beyond the imagined boundaries of enclosing indigenous communities ... Once turned into proprietary information in the new information economy, however, it will cease to be 'ours'. This information will be simply incorporated into new monopolies to which public interests will be subjected and human beings subjugated unless we demand that decisions about the scope of patents be recognized as political choices in which we all have some stake. (p. 507)

Thus practical realities belie the rhetoric. To many indigenous peoples (e.g. the Maori) genes are equivalent to genealogy: the ancestors are present in genes - and, physiologically, that is true. Whitt (2009) cites a comment by Mead, who stressed that:

the indigenous and western philosophies differ on this fundamental point ... it is the difference in understanding of the origin of humanity, the responsibility of individuals, and the safety of future generations which sits so firmly at the core of indigenous opposition to the [Diversity Project] ... this type of research proposes to interfere in a highly sacred domain of indigenous history, survival and commitment to future generations. (p. 121)

All this illustrates the complexity of the problem. Cultures that accentuate individual autonomy differ from communityoriented cultures that stress the collective. But who decides to consent to the HGDP in indigenous and other cultures? That would surely depend on the closeness of the group. Whitt (2009) quotes an aboriginal activist:

We assert that our identity and our rights are not reducible to the rights of individuals ... With its cult of the individual and its emphasis on individual rights, non-indigenous people in the western world have failed to acknowledge the collective nature of indigenous societies, and have provided inadequate protection for the group rights of peoples. (p. 124)

In the South African context, there are no ethnic groups so isolated or close-knit that the chiefs or kings can speak for all members of the tribe. Although guidelines have been laid down stipulating that indigenous groups have to consent to the project, it does not prevent individual group members from responding on their own and offering their genome for mapping. ${ }^{15}$ In this context, black market operations and what is known as bio-piracy are also relevant.

15.See Indigenous Peoples Council on Biocolonialism (2007). It has the limitation that the document focuses on indigenous groups in reserves. In South Africa, indigenous groups are no longer confined to particular tribal areas (reserves or 'homelands').
The question is: does a group own its genome? As stated above, does my genome belong to me in the sense that I own a patent to it? We all receive life for free.

\section{The South African position}

The United Nations (UN) report on life expectancy for 2005-2010 lists 194 countries. It is topped by Japan with an average life expectancy of 82.6 years. Fifteen countries have an average life expectancy above 80 years and 100 of between 70 and 80 years. South Africa ranks 178th and Swaziland is bottom of the list with an average of 39.6 years. The bottom 40 countries are all in Africa. Considering that humankind initially migrated from Africa, which is recognised as the cradle of the human race, this is a tragic irony indeed. How will Africa benefit from the HGP? We know that there are justified reservations about the feasibility of the African National Congress (ANC) government's national health plan, because it is simply too expensive. When the benefits of the HGP become available to the populace as a whole, the price will be way beyond the means of the average African. So why should Africans take part in the project at all?

South Africa has adopted the guidelines of the American National Institute of Health. It is submitted, however, that developing countries such as South Africa have many other more basic health care problems on which to spend their limited resources, despite having the technology to practice gene therapy.

The Human Genome Initiative has stimulated worldwide research into humankind's genetic structure. It has led to identifying and understanding the function of many genes which cause illnesses, deformities, organ malfunctions and, more recently, behavioural aberrations. The science of gene therapy has developed in tandem with this and has initiated therapeutic treatment by replacing defective genes in humans. In the legal sphere guidelines for the application of gene therapy have been recommended by, for example, the Council of Europe, the United Kingdom, France, Denmark and the USA.

As for ethical perspectives, it may be virtually impossible to arrive at a universal ethics because of differences in accent between, for instance, Christians, Muslims and indigenous Africans. How can African cultures contribute meaningfully to the project? The following are some possibilities. The contribution that fairly isolated groups in Africa can make to understanding of the human genome is crucial. Africans from various geographical areas can protest against biocolonialism if they are subjected to it. South Africans may protest against Western greed and exploitation on the basis of Ubuntu ethics. Africa is regarded as the cradle of human life, hence has the same claim as all other countries to the benefits of knowledge about the human gene that evolved here. Protest against bio-abuse can also be based upon the international culture of human rights, insisting that medical benefits should be available to everyone as cheaply as possible. South Africans can claim benefits emerging from 
genome research on the basis of its contribution to biological, medical and other research (e.g. Sydney Brenner and Chris Barnard). It also makes sense that scientists representing all countries should be involved in genome research. South Africans may request that scientific knowledge, especially knowledge affecting the human right of access to health services, should be freely available, together with a challenge to inform people about what genome research entails. South Africans should insist on the implementation of measures to enhance respect for all life and the environment, including the prohibition of trans-genetic research. An ethos of respect should be promoted, as far as possible, for all cultural and religious views that differ from a one-sided worldview that may arise from knowledge about the human genome. South Africans should also, in light of their history of repression, combat any form of racism or superiority that may results from genome research (HapMap programme) or related research.

\section{Conclusion}

This article addressed the presumed conflict between science (genome research) and religion (belief in miracles) and has endeavoured to make space for both disciplines to flourish in light of a changing world view. Although science has in some sense (Modernism) contributed to the disenchantment of the world, it has also added to the depth and complexity of nature. Reductionism (of what life is) is always a real possibility and should be countered. The outcome of genome research will contribute to a changing worldview. It confirms our evolutionary past, our relatedness with the rest of nature and especially of humans. We are all $99.99 \%$ the same and any notion of race superiority is obsolete.

Genome research concerns every South African. We may all benefit from research conducted both nationally and globally. The mapping of the individual genome supports individualised medication, which may make a significant difference in treatment. This, however, is presently quite expensive and only accessible for the rich. Some boundaries of genome research have been indicated and some threats it entails for religion have been dealt with (with specific reference to the question of determinism).

The issue of genome patenting has been resolved to some extent, but the issue of compensation for contributors, especially from Africa, is still outstanding. Africa is the cradle of humankind and genome research underscored this. There is more sequence variation within people in Africa than outside. This variation is of considerable importance, as it is likely to be the basis of individual susceptibility and resistance to disease.

The HGDP in the South African context was highlighted and some guidelines for our participation in the HGP have been suggested. South Africans should be well-informed about developments in genome research and how it may affect them. The challenge for religion, apart from ethical reflection, is to ensure that the benefits of genome research will be available to all, especially the poor.

\section{Acknowledgements Competing interests}

The author declares that he has no financial or personal relationships that may have inappropriately influenced him in writing this article.

\section{References}

Amani, B. \& Coomby, R.J., 2007, 'The human genome diversity project. The politics of patents at the intersection of race, religion, and research ethics', in W.T. Gallagher (ed.), Intellectual property, pp. 152-188, Ashgate, Aldershot.

Appleyard, B., 1992, Understanding the present: Science and the soul of modern man, Picador, London.

Baxi, U., 2007, Human rights in a posthuman world, Oxford University Press, Oxford. PMCid:PMC2359602

Hewlett, M.J., 2004, 'Darwin, and doxology: A contemporary conversation between biology and faith', in R.J. Russell (ed.), Fifty years in science and religion. Ian $G$ Barbour and his legacy, pp. 185-190, Ashgate, Aldershot.

Indigenous Peoples Council on Biocolonialism, 2007, Declaration on Indigenous peoples' rights to genetic resources and Indigenous knowledge, viewed 10 October 2011, from http://www.ipcb.org/resolutions/htmls/Decl_GR\&IK.html

Kandel, E.R., 1976, Cellular basis of behavior, W.H. Freeman and Company, San Francisco. PMCid:PMC1653367

Kauffman, S.A., 2008, Reinventing the sacred. A new view of science, reason and religion, Basic, New York.

M'charek, A., 2005, The human genome diversity project. An ethnography of scientific practice, Cambridge University Press, Cambridge. http://dx.doi.org/10.1017/ CBO9780511489167

Neumann, H., Eva, M. \& Rehmann-Sutter, C. (eds.), 2009, Genes in development, Duke University Press, Durham.

Peters, T., 2003, Playing God? Genetic determinism and human freedom, Routledge, London.

Regis, E., 2008, What is life? Investigating the nature of life in the age of synthetic biology, Oxford University Press, Oxford.

Richards, J.E. \& Hawley, R.S., 2005, The human genome, 2nd edn., Elsevier, San Diego.

Spong, J.S., 2007, Jesus for the non-religious. Recovering the divine at the heart of the human, Harper, San Francisco.

US Supreme Court, 2013, Association for Molecular Pathology et al. v. Myriad Genetics, Inc. et al., viewed 18 December 2013, from http://www.supremecourt. gov/opinions/12pdf/12-398_1b7d.pdf

Waters, B., 2006, From human to posthuman. Christian theology and technology in a postmodern world, Ashgate, Aldershot.

Watson, J., 2003, DNA. The secret of life, Arrow, London.

Whitt, L., 2009, Science, colonialism, and indigenous peoples. The cultural politics of law and knowledge, Cambridge University Press, Cambridge. http://dx.doi. org/10.1017/СBO9780511760068

Wilson, E.O., 2003, The future of life, Alfred A. Knopf, New York. 